\title{
COMPUTER VISION SYNDROME AND NECK RANGE OF MOTION IN OFFICE EMPLOYEES
}

\author{
Christin Setiawan $^{1)}$, Titiek Ernawati' ${ }^{2)}$, Nunung Nugroho ${ }^{3)}$
}

\begin{abstract}
Introduction: A lot of employees working in front of a computer complaining about some symptoms. Eye and vision problems connected to the prolonged use of a computer are called Computer Vision Syndrome (CVS) or Digital Eye Strain. One of the symptoms of CVS is neck pain. In comparison, Range of Motion (ROM) is used to determine the ability of joint movements. Aside from that, it can also be used to maintain flexibility and joint mobility.

Purpose: To explain the association between Computer Vision Syndrome and the reduction in neck range of Motion in Employees.

Method: The type of this research is analytic observational, and the design of this research is Cross-Sectional Study. This research was conducted from Tuesday, 16th July 2019, until Wednesday, 17th July 2019, using CVS-Q and goniometer dy.

Results: We collected 156 respondents that meet the inclusion and exclusion criteria. We obtain $\mathrm{p}=0,02, \mathrm{p}<0,05$ meaning there is an association between Computer Vision Syndrome and the neck range's Motion.

Conclusion: To conclude, there is an association between Computer Vision Syndrome and the neck range's Motion.
\end{abstract}

Keywords: Range of motion, computer vision syndrome

\footnotetext{
${ }^{1)}$ Student of Faculty of Medicine, Widya Mandala Surabaya Catholic University Indonesia, Jl. Kalisari Selatan No.1 Surabaya Email: christin1299@gmail.com

${ }^{2)}$ Opthalmology Department, Faculty of Medicine, Widya Mandala Surabaya Catholic University Indonesia, Jl. Kalisari Selatan No.1 Surabaya

${ }^{3)}$ Medical Rehabilitation Department, Faculty of Medicine, Widya Mandala Surabaya Catholic University Indonesia, Jl. Kalisari Selatan No.1 Surabay
} 


\section{INTRODUCTION}

Twenty years ago, the invention of computers resulted in a revolution of working style. Computers have become an essential part of daily living. Almost all institutions, colleges, universities, and homes use computers. Computers allow workers to get more information in a short time. According to the research of the Ministry of Communication and Information of the Republic of Indonesia (KOMINFO) 2017, number one computer users are at home with $61.92 \%$. Number two is office $42.08 \%$. Over the past decade, increasing usage of computers in the workplace has caused several health problems. ${ }^{(1)}$

Many people who work using computer complain of various health problems. Eye and vision problems associated with prolonged use of computers are called Computer Vision Syndrome (CVS) or Digital Eye Strains. CVS has various symptoms, including eye strain, headache, dry eyes, neck and shoulder pain. Not only computers but for tablets, games, mobilephones are devices that can cause CVS. Nearly 60 million people suffer from CVS globally.

According to Anggraini's research in 2012, 78 respondents in PT. Bank Kalimantan Barat were experiencing CVS disruption of $88.5 \%$. ${ }^{(3)}$ Therefore, it is likely that CVS will continue to create significant reduction in productivity in the workplace and reducing office workers' quality of life.

Range of motion (ROM) is a term for determining ability of joint motion. It also means an exercise that aims to maintain the flexibility and mobility of the joints. ROM has a function to reduce joint stiffness. Stiff joints can cause pain and make it difficult for someone to do normal daily activities. Neck ROM measurements have been used to evaluate the severity of disorder or disability in patients with workrelated cervical spine disorders and injuries. ${ }^{(4,5)}$ In a study in Abbasia, Mezir, of 202 workers in a company, 48 people experienced musculoskeletal neck pain (53\%) and lower back pain (52.5\%). These were the most reported musculoskeletal symptoms. ${ }^{(6)}$

The high burden in the previous studies is why the researcher wants to know the prevalence of CVS in the company. CVS can cause pain in the neck and reduce the ROM of the neck joint. We aim to analyze the association between CVS and ROM of the neck joint because there is no such study.

\section{METHOD}

This research is an observational analytic research with cross-sectional 
study design. cross-sectional study is appropriate for explaining the status of a phenomenon or explaining the relationship of a sensation at one point in time.

This research was conducted to explain the CVS association against the ROM of the neck joint. The population of this study is the company employees who use computers at least 4 hours a day.

The inclusion criteria of this study are: Company employees who use computers at least 4 hours a day and willing to be the subject of research and sign the informed consent form for respondents. While the exclusion criteria of this study are: Not present in the study, Do not agree to participate in the study, company employees who have basic illnesses of neck disorders and neck injuries can be examined using Schober test beforehand, and employees who use contact lenses, eye trauma, history of eye surgery, use eye medicine.

The sampling used in this study was nonprobability sampling, where this technique prioritizes certain criteria and characteristics. the technique used was consecutive sampling. Consecutive sampling is sampling based on specific considerations about the inclusion and exclusion criteria.
The study was conducted on Tuesday, July 16, 2019, until Wednesday, July 17, 2019, starting at 08.00-23.00. Retrieval of data used in this research is primary data where researcher use CVS-Q that is, previously validated $\mathrm{P}<0.05$ and the reliability of the questionnaire obtained a Cronbach's alpha value of 0.882 or $82 \%$ and measurements using a goniometer to respondents.

Before conducting research, the researcher took demographic data from respondents in the form of gender and age. Respondents who worked at that time were 156 respondents. Then the researcher gives CVS-Q to measure whether the respondent experiences CVS disorders or not, where if the score $\geq$ six, then the respondent experiences CVS. Then the neck ROM was measured by using a goniometer. Respondents did several movements, namely Flexing of the neck or moving the chin to the chest with the normal limit 0 $45^{\circ}$, neck extension or bending the head back with the normal limit $0-45^{\circ}$, lateral flexion or tilting the head towards each shoulder with the normal limit $0-45^{\circ}$, and rotation or turning the head in a circular motion with normal limits $0-90^{\circ}$.

\section{RESULTS}

Characteristics distribution based on age and sex 
Table 1. Respondents characteristics distribution

\begin{tabular}{|c|c|c|c|}
\hline No & \multicolumn{2}{|c|}{ Respondents characteristics } & $\mathrm{n}(\%)$ \\
\hline 1. & Sex & Male & $\begin{array}{c}65 \\
(51,6)\end{array}$ \\
\cline { 3 - 4 } & & Female & $\begin{array}{c}61 \\
(48,8)\end{array}$ \\
\hline 2. & Age & $\begin{array}{c}<45 \text { years old } \\
\text { (middle age) }\end{array}$ & $\begin{array}{c}108 \\
(85,7)\end{array}$ \\
\cline { 3 - 4 } & $\begin{array}{c}\geq 45 \text { years old } \\
\text { (elderly) }\end{array}$ & $\begin{array}{c}18 \\
(14,3)\end{array}$ \\
\hline
\end{tabular}

Table 2. Association CVS and ROM neck company employees

\begin{tabular}{|c|c|c|c|c|c|c|c|}
\hline \multirow{3}{*}{$\begin{array}{c}\text { Varia } \\
\text { ble }\end{array}$} & & & & & \multicolumn{2}{|c|}{ Total } & \multirow{3}{*}{$\begin{array}{c}\mathrm{P} \\
\text { (asy. } \\
\text { Sig) }\end{array}$} \\
\hline & \multicolumn{2}{|c|}{$\begin{array}{c}\text { ROM } \\
\text { decre } \\
\text { ase }\end{array}$} & \multicolumn{2}{|c|}{$\begin{array}{l}\text { ROM } \\
\text { normal }\end{array}$} & & & \\
\hline & $\mathrm{n}$ & $\%$ & $\mathrm{n}$ & $\%$ & $\mathrm{n}$ & $\%$ & \\
\hline \multicolumn{7}{|l|}{ CVS } & \multirow[t]{4}{*}{0,002} \\
\hline Yes & 66 & $\begin{array}{c}52, \\
4\end{array}$ & $\begin{array}{l}1 \\
0\end{array}$ & $\begin{array}{l}7, \\
9\end{array}$ & 76 & $\begin{array}{c}60 \\
3\end{array}$ & \\
\hline No & 35 & $\begin{array}{c}27, \\
8\end{array}$ & $\begin{array}{l}1 \\
5\end{array}$ & $\begin{array}{c}11 \\
9\end{array}$ & 50 & $\begin{array}{c}39 \\
, 7\end{array}$ & \\
\hline Total & $\begin{array}{c}10 \\
1\end{array}$ & $\begin{array}{c}80, \\
2\end{array}$ & $\begin{array}{l}2 \\
5\end{array}$ & $\begin{array}{r}19 \\
, 8\end{array}$ & $\begin{array}{c}12 \\
5\end{array}$ & $\begin{array}{l}10 \\
0, \\
00\end{array}$ & \\
\hline
\end{tabular}

\section{DISCUSSION}

Based on the results of the ChiSquare analysis test, the value of $p=0.002$ where $p<0.05$, which means that there is a significant association between CVS and the ROM of the company's employees.

These results are supported by a theory from Treleaven J and Ischebeck BK where the decline in vision occurs when the body reflexes. There are two reflexes, namely vestibule-ocular reflex (VOR), which aims to stabilize the position of the head and stabilize the picture on the retina. In contrast, the cervical-ocular reflex (COR) seeks to respond to head movements. ${ }^{(31,32)}$

Using a computer for more than 4 hours can result in a non-neutral position for an extended period. Non-neutral position for a long time will result in muscle fatigue. This muscle fatigue comes from the presence of ischemia or depletion of energy (ATP), where the muscle cannot produce new ATP. If this happens, the production of ATP will be diverted by the anaerobic method. The anaerobic process results in lactic acid accumulation. Lactic acid is a by-product of glycogen breakdown and can cause neck pain. This neck pain allows interference with ROM. (8-10) Therefore, this study has similarities with previous studies.

\section{CONCLUSION}

The results of the study with the title "Association of Computer Vision Syndrome Against Range of Motion of the Employees Neck of the Company" conducted on July 16, 2019, to Wednesday, July 17, 2019, with a sample of 126 respondents can conclude that there 
is an association of CVS Against the ROM of the neck joint.

The research has limitations, the prevalence of different respondents at the age of fewer than 45 years with more than 45 years. In addition, the weakness of this research is that taking data through questionnaires and measurement of goniometry can be subjective. Therefore it is better to control by using an ophthalmologist to manage the variable CVS-Q and use physiotherapy to measure neck ROM.

\section{ACKNOWLEDGEMENT}

1. Thanks to all respondents who participate in this study

2. Friends of the Faculty of Medicine, Widya Mandala Catholic University Surabaya, class of 2016.

\section{REFERENCES}

1. Kemenkominfo. Survey

Penggunaan TIK Serta

Implikasinya terhadap Aspek

Sosial Budaya Masyarakat. 2017;12; 26-30.

2. American Optometric Association. The Effects of Computer Use on Eye Health and Vision. Am Optom Assoc. 1997;
3. Anggraini Y. No Title. Faktor Faktor yang berhubungan dengan terjadinya keluhanan Computer Vision Syndrome pada Operator PT Bank Kalbar Kantor Pusat Tahun 2012.

4. Therapist P, Rom A, Rom P. Passive and Assistive Range of Motion Exercises. 2004;1-12.

5. Strimpakos N. The assessment of the cervical spine. Part 1: Range of motion and proprioception. $\mathrm{J}$ Bodyw Mov Ther [Internet]. 2011;15(1):114-24. Available from:

http://dx.doi.org/10.1016/j.jbmt.20 09.06.003

6. Gabal MS, Elaziz KMA, Mostafa NS, Almadani TA. Computer Vision Syndrome and Musculoskeletal Disorders among call center workers of a private company. Egypt J Community Med. 2017;34(4):51-7.

7. Farooq MN, Mohseni Bandpei MA, Ali M, Khan GA. Reliability of the universal goniometer for assessing active cervical range of motion in asymptomatic healthy persons. Pakistan J Med Sci. 2016;32(2):457-61.

8. Anshel J, editor. visual ergonomics. 2005 
Ischebeck BK, de Vries $J$, van

Wingerden JP, Kleinrensink GJ, Frens

MA, van der Geest JN. The influence

of cervical movement on eye stabilization reflexes: a randomized trial. Exp Brain Res [Internet]. 2018;236(1):297-304. Available from: http://dx.doi.org/10.1007/s00221-0175127 